SeCUritly
$327.51 .071 .51(497-1554-672 \mathrm{E})$

\title{
EU Perspective of the Western Balkans Countries: Why and How Can Croatia Help?
}

\author{
Lidija Čehulić Vukadinović, \\ Faculty of Political Sciences, University of Zagreb
}

\begin{abstract}
Croatia's neighbors, as well as other Western Balkans countries, are striving to join the EU at the time when the Union's internal crisis has still not been completely overcome. It is not quite sure when the EU is going to open its door to new members again. Of all new post-socialist member states, within the EU, Croatia is the first post-conflict country accepted to the membership. Not all of the Western Balkans countries were involved in the wars and the armed conflicts after the dissolution of former Yugoslavia. However, their overall social development is taking place in times when many issues in the region remain unresolved (security, political, economic, ethnic) but at the same time the new challenges have emerged (energy supply, radicalization of Islam, illegal migrations, Ukraine, ISIS). Additional criteria and conditions that EU will eventually impose on the Western Balkan countries will be either as difficult as those that had to be met by Croatia or even more complex. With its negotiating experience Croatia could and should unselfishly assist the countries in the region. On the other hand, based on many social indicators Croatia is still among relatively weak EU members. Being a peripheral member, any new destabilization of the neighboring region is not in Croatia's national interest, same as it is not in the EU's interest. Integration of the Western Balkans region into the EU would enable Croatia not only to strengthen the perception of its security, but would also create a much more compatible area for its economic activities within the Union. Croatia has declared the support to the Union's further enlargement to other Western Balkans countries as its goal within the EU. Having in mind Croatia's declared readiness for further enhancement of good neighboring relations and functional regional cooperation in the Western Balkans, Zagreb should position itself as a stable, consistent and recognizable leader of a coalition within the EU that will permanently advocate for its further enlargement.
\end{abstract}

Keywords: Croatia, EU Integration, Western Balkans, enlargement, assistance 


\section{Securiaty}

\section{The Western Balkans after Croatian Accession into the EU}

After the more than eight years of accession process (the longest one in comparison with all other post-socialistic countries which entered the European Union), Croatia become the $28^{\text {th }}$ member-state of the European Union (2013) during the financial crisis. That first EU enlargement since Euro crisis will, for sure, also be the last in this decade. Under the most positive scenario, the EU membership even for the most credible aspirant from the region of Western Balkans (Montenegro) technically is not realistic before 2020. Due to EU's own internal political, fiscal and social crisis, which was resulted with a huge enlargement skepticism inside the EU, the accession process has become more difficult and rigorous. The old EU members now have much more opportunities to block the process. Contrary, more optimistic observers claim that the accession process of the Western Balkans is steadily moving ahead, albeit at a slower pace. The Western Balkans (political term introduced during the 2000 EU summit in Zagreb) embraces Albania, Bosnia and Herzegovina, Croatia, Kosovo, Macedonia, Montenegro and Serbia. Till now, only Croatia is full-fledge member of EU but all other countries are either candidate or aspirants for membership. Croatia, as a border country of the European Union, together with Bulgaria and Romania are still relatively weak countries inside the EU and as a neighborhood countries are exposed and suffering from all instabilities and weaknesses in the Western Balkans. Unfortunately, the overall situation in that part of the Europe is much worse than two years ago when Croatia joined the EU.

\section{a) Economic stagnation}

According to the analysis of the World Bank economist, Branko Milanovic, who has reviewed the experience of twenty five years of transition in post-socialist Europe, based on criteria of progress in political democratization, growth in income per head and trends in income inequality, no country from the Western Balkans is successful. Instead of consolidating post-socialistic economic reforms, integrating into the European and world economy, attracting foreign investment and reorienting trade to the West, the overall economic transition of the Western Balkans has stalled. ${ }^{1}$ Growth in the area is weak and fragile The Western Balkans suffers from low investment, emigration rate is very high and ${ }^{1}$ http://country.eiu.com/article.aspx?articleid=1473010731\& Country=Croatia\&topic=Economy\&subtop
ic=Regional+developments\&subsubtopic=Economic+growth, detached July 10,2015. 
average unemployment is around $1 / 4$ of the adult population. Serbia has an unemployment rate above 25 percent, Macedonia over 30 percent and Kosovo over 40 percent. In 2014 the real GDP in the Western Balkans was still almost ten percent below its 1989 level. GDP per capita was only 27 percent of the average level of the EU members, and roughly half the average level in the 2004-2007 joiners. The average ratio of public capital spending in GDP in 2013 was only 5.4 percent, mainly investments in motorways (The Economist, March 24 2015). The economic forecasts indicate that there will be little change in economic performance in the next five years. That will increase the gap between the Western Balkans countries and the EU members.

According to the IMF report The Western Balkans: 15 Years of Economic Transition, the priority reform areas in the Western Balkans are: quality of governance, efficiency of goods markets, labor market, human capital, and financial system. All of that is a long term task and majority of Western Balkans countries have lost the so-called reform momentum in the beginning of 90 -ies. Due to the bloody disintegration of Yugoslavia the economic transition has had three main phases. The first one was the lost one; the decade immediately after the dissolution of former Yugoslavia, characterized by the wars (19891995) and hesitation of political elites to perform the structural economic reforms (19952000). The Yugoslav market was destroyed, international community imposed economic sanctions upon some of the newly established countries. The GDP in the region in 1994 was 60 percent, and in the 2000 - 40 percent below its 1989 level.

The second phase of economic transition to market economy system took place from 2001 till the 2008 crisis. The economic boom of that period was based on an unsustainable pattern of increased consumption liked to fast credit growth. The countries of the Western Balkans underwent a major economic transformation, starting rebuilding their war-torn economies and moving forward to market-based system. They opened up to the global trade, became increasingly export-oriented, dismantled some regulations that stifled business development, expanded the role of the private sector, banking systems were built up with the aid of foreign capitals and know how. The results of these reforms have been a significant rise of living standards and incomes of local people, robust economic grow that enhanced macro-economic stability (Murgasova and an IMF Staff Team, 2015). That gave the Western Balkans countries the illusion, albeit temporarily, that the fast economic growth was possible without completing the reforms and transformation process.

During and after the economic crisis (the third phase) the Western Balkan countries, including Croatia, have faced economic stagnation. According to the World Bank, 
no other region in Europe has experiencing greater shock from the fiscal and economic crisis and it has projected a further drop of GDP in all countries in the region (The World Bank Report, 2012). No country is a functioning market economy yet. All of them have to create and implement specific national economic strategy to achieve sustainable growth and to improve their competitiveness.

In terms of structural reforms the region lags well behind the other post-socialistic countries of Ccentral and Eastern Europe. Western Balkans was slower because the structural reforms proceeded more slowly. All countries are facing high fiscal deficits and public debt, many inefficient state-owned enterprise remain to be privatized, the new jobs have to be generated and, what is equally important, the way of governance has to be improved (Murgasova and an IMF Staff Team, 2015)

The process of accession to EU membership was the main catalyst of reforms. Now with the enlargement fatigue within the EUe and many reforms left incomplete, the faster stabile economic growth remains an illusion. Trade plays an important role in the EU's efforts not only to achieve the economic prosperity in the Western Balkans, but to promote peace, freedom and stability in that region. The EU is the Western Balkan's largest trading partner, accounting for over 75 percent of the regional total trade. On the other side, the total share of all Western Balkans countries was 1.1 percent of total EU's trade in 2014. Individual countries shares were very low: Serbia 0.50 percent, Bosnia and Herzegovina 0.20 percent, Macedonia 0.20 percent, Albania 0.10 percent, Montenegro 0.10 percent. In 2014 the EU import and export from Western Balkans was mainly machinery and transport equipment (26,5 percent and 27,0 percent). ${ }^{2}$ The EU was and still is the largest donor to the region, thus strongly supporting the membership of the Western Balkans countries to the WTO.

In comparison with other newcomers from East and Central Europe, the specific path of Western Balkans countries has been created by some factors with undermining effect on the reforms. According to the IMF these factors include: inexperienced bureaucracies, history of unrest, ethnic and border disputes, high unemployment, nonconsolidated democracies, very high level of popular dissatisfaction with politicians. Majority of them are connected with the lack of overall democratization. ${ }^{2}$ http://ec.europa.eu//trade/policy/countries-and-regions/regions/western-balkans/, detached July
152015 


\section{b) Political stagnation}

The Western Balkans faces risk of permanent marginalization on the periphery of the Old Continent. The EU membership however is not the panacea for all problems. At the 2003 Thessaloniki summit the EU granted the region a clear perspective of membership, subject to fulfillment of the necessary conditions. But the rule of law is now at the heart of the enlargement process. In 2011 a new approach was adopted: candidate countries have to tackle issues such as the fight against organized crime, corruption and the judicial system reform early in the negotiation process. Strengthening the rule of law, independence of judiciary and further progress in the fight against corruption and organized crime are important for strengthening citizens trust in state and public institutions (Borzel 2011). This approach is a key element of the negotiating framework with Montenegro and will definitely be used for the other countries.

Regional cooperation and good neighborhood relations are crucial to overcome the legacy of the past (Sefearj 2015). Still issues related to the recent wars and conflicts, including border disputes, missing persons, return of all expelled people, refugees and their private properties, prosecuting of war crimes have to be addressed. Treatment of minorities and ensuring equal rights for all citizens remain key challenges to stability in the Western Balkans (Veljanoska, Andonov and Shibakovski, 2014). Open bilateral issues between the countries should not hold up the accession process. Some EU countries use these unresolved issues to further postpone the enlargement process. The countries should make efforts to put their bilateral disputes on the table and try to solve them in good faith. Croatia should offer political support and facilitation to all countries concerned to find solution to bilateral issues as early as possible. In order to promote all kind of regional and cross-border cooperation, Croatia should fully support the work of the Regional Cooperation Council, Regional 2020 Strategy and the South-East Cooperation Process.

Enlargement process depends on the support of the citizens of the EU as well as these from the aspirant countries. Besides the formal institutions dealing with the enlargement, the strong public support is also needed. NGOs are needed for providing citizens with information and education about the costs and benefits of the integration process on all levels: political, economic, social, security. Croatian experts, NGOs, people from academia can help by sharing experience and knowledge with the civil societies of the Western Balkans countries. The International summer schoo/ on island Šipan, organized for fourteen years by the Croatian's NGOs: The Atlantic Council of Croatia and Centre for 
International Relations is one positive and very educative example of spreading the European and Euro-Atlantic ideas among the young people from the region. Yearbook Sipan has been published as a collection of the presentations in the International summer school for thirteen years, covering the topics connected with the Western Balkans and European and Euro-Atlantic integrations.

\section{c) New security challenges and risk}

The regional security has been endangered by activities of internal and external actors. The recent history was dominated by armed conflicts, crises and disputes among the Western Balkans countries. Foreign forces are still present in Bosnia and Herzegovina and Kosovo. (Croatia is contributing to KFOR). Although the possibility of new military conflicts cannot be absolutely excluded, the main security challenges are connected with the asymmetric threats. They are much higher predictable and of changeable intensity.

With the economic and financial crisis, the social problems have increased, especially in the rural and underdeveloped regions, while the position of all kind of marginalized groups in these countries (sex, ethnic, religious....) is becoming increasingly harder. This is an important factor which has influenced an increase in criminal activities and illegal migrations. (Božić 2011, 61).

The Western Balkans again becomes an area where different kinds of organized crimes and high level of corruption are present. Further strengthening of cooperation amongst the police, judiciary, customs and other institutions, training of law enforcement personnel are very much needed. Regional cooperation is of particular importance as well as cooperation with the EU special agencies and institutions. Enhancing cooperation can improve the security in the region and beyond. Still the fight against corruption and organized crime depends mainly upon the request from the EU or other foreign institutions. There is less proactive action of domestic institutions and not enough exchange of information between the countries about the criminal activities in the region. All relevant institutions: EUROPOL, European Police College, Secretariat of Police Cooperation, Convention for Southeast Europe, Southeast Police Chiefs Association and Southeast European Prosecutors Advisory Group see the Western Balkans not only as an area of origin, but an area of transit routes and an area suitable for organizing training camps for different criminal and terrorist activities (Annual Report on Regional Cooperation in South East Europe 2014-2015 „24-26). 
Migration is a matter of critical importance for the region, particularly in view of the liberalized visa regime (all countries except Kosovo). When Hungary is going to protect/close its border with Serbia (building the 175 kilometers long wall), the other countries (Montenegro, Bosnia and Herzegovina, Croatia) will face much higher number of people trying illegally enter the EU. Migration and border management issues are addressed both within the Stabilization and Association Agreements, and Chapter 24 of the negotiations with the accession countries. The Migration, Asylum and Refugees Regional Initiative is the only common existing coordination mechanism that should provide strategic direction in migration management. To prevent illegal migration and related organized and cross-border crimes, promoting networking between EU and Western Balkans countries as well as specialized agencies and institutions is needed. As was written in one policy paper of Central European Policy Institute, there is a silent pact between the enlargementfatigued and crisis-hit EU member states and rent-seeking Balkan elites who do not mind slowing the pace of reform with a fire-brigade approach to periodic crises and outbursts of violence in the Western Balkans (The Visegrad Group 2015, 2). Due to the high level of corruption and weakness of states institutions the Western Balkans becomes heaven for money laundering, smuggling of drugs, arms and humans.

In such poor socio-economic environment the separatist ideas and aspirations, religious extremism, ethnical disputes and hard nationalists are in rise (Bugajski 2014). Some extreme radical groups possess hidden arms and they have started to organize trainings for people (local and coming from abroad) who are going to join ISIL. Recently, some terrorist attacks were conducted in the area of the Western Balkans (Zvornik, Kumanovo).

In the times of resettling US-Russian relations, geostrategic position of the Western Balkans countries (especially those with traditionally good relations with Russia) can serve as a transitional corridor for the protecting energy supply of wider Europe. Although the overall destabilization of the Western Balkans poses far less of a threat to EU than the Ukraine crisis, Middle East or ISIS's barbarism, it is far less difficult challenge to overcome. In the Western Balkans there are no nuclear weapons and till now, terrorist attacks are rare (Joseph 2015). Even the most problematic countries are striving to join EU. But with no meaningful policy of carrots and sticks the EU has left responsibility to the region's leaders and paid a sporadic attention to the security and stability of the region. 


\section{Securiaty}

\section{Weak and Unstable Western Balkans Does Matter to Croatia}

As the first post-socialist and post-conflict country that joined EU (Čehulic Vukadinović 2013), Croatia observes more attention within the Western Balkans as well as within the European Union members. In comparison with other countries from Central and Eastern Europe who joined the EU in 2004/2007, Croatia is the only country with war legacy. To qualify for membership Croatia has not only fulfilled the Copenhagen criteria but more importantly has radically changed its political culture. It stopped disrupting state building in Bosnia and Herzegovina, allowed return of Serb refugees, engaged Serb minority party into a government coalition and completed the extradition of all indicated by the Hague Tribunal (Knaus and Bender 2012). Fight against corruption and human trafficking, as well as strengthening structural economic reforms are the main tasks that $\mathrm{EU}$ is still strongly looking for. But the transformation of Croatia would not have been possible without the negotiation process that started in 2005. Concerning major socio-economic factors, Croatia is still relatively week and poor member (SGI Survey 2015). Croatia's failure will definitely slow down the further enlargement especially in the light of the Greek crisis.

On the other hand, aspirants for membership pay great attention on Croatia too. Coming from the same geopolitical, economic, historical and cultural region with the common recent past, they are interested to see the benefits Croatia will gain. During the negotiation process Croatia was dealing with the Western Balkans because of the necessity of normalization of neighborly relations. Joining the EU had great psychological significance for Croatia. It was a sort of escape from the Balkans. But as a second-class member within the EU, due to its internal weaknesses and unfinished reforms, Croatia has recognized that it cannot escape from the region. Through adjustment of its economic policy and diplomacy, Croatia tries to reinforce ties with the countries in the region, even with former enemies. New developments in the EU and very complicated international situation, particularly in the Mediterranean region, Croatia has recognized that it is in her best interest to help the other countries from this fragile corner of Europe to join the EU as soon as possible.

Concerning further EU enlargement, Montenegro has the greatest chances of entry. It has opened the negotiation talks in 2012 and closed two chapters. Public administration reform is a priority to ensure capacity to apply the acquis. Montenegro is the test case of the new EU approach to the accession process, with more emphasis on the chapters 23 and 24. With its negotiation experience and know how Croatia should help Montenegro on its reforms. But what Montenegro is waiting for, concerning integration 
process, is the call for the full membership to NATO. If NATO is not going to extend it till the end of 2015, probably all other reforms will be postponed or even stopped. One can expect new social upheaval.

Macedonia depends on solving the name issue with Greece. Lack of a credible EuroAtlantic and EU perspective put at risk the sustainability of the all reform efforts. Overall political, economic and especially security situation is much worse than it was in 2008 when Greece blocked the Macedonians entry to NATO. Macedonia was the first state in the region to establish institutional ties with both NATO and EU. It did very well in the framework of NATO's programs PfP and Membership Action Plan as well as in the framework of EU's Stabilization and Association Agreement. Macedonia has participated in the EU peace operations in the framework of the Common Security and Defense Policy (Xhaferi 2015). That Euro-Atlantic and European integration has been part of the formula which has saved Macedonia from the brink of the civil war. The Ohrid Agreement and Roma Strategy, as a foundation for inter-ethnic relations, have started to implement (Mitrevska 2014). Greece will be persistent in its blocking Macedonia on its path to NATO and EU. In order to prevent destabilization of Macedonia (terrorist attacks included), Brussels should be involved and put some political pressure on both sides (Athens, Skopje) in order to find solution for the name issue.

Serbia is the key county in the region due to its size, central location and influence it might have on several neighboring states (Kosovo, Bosnia and Herzegovina-Republic of Srpska, Montenegro). EU is not very satisfied with the Serbian pro-Russia orientation in key aspects (political relations, energy supply, enhanced economic and military cooperation). Current government in Belgrade does not care very much for EU's calls for strategic choice between EU and Russia. Serbia has to find a way for normal coexistence with Kosovo even if Kosovo is not fully recognized as an independent state from five EU countries (Cyprus, Greece, Romania, Slovakia, Spain). When Serbia has started to work actively and constructively toward a visible and sustainable improvement of its relations with Kosovo, EU has granted it with the Stabilization and Association Agreement, candidate status and now Brussels is ready to open the accession negotiations. Unfortunately Serbia's institutional progress is not a result of implemented reforms. It is a gift of EU based on its stick and carrot policy with regard to the Serbia/Kosovo dispute.

The same goes to Kosovo. As a result of Prishtina/Belgrade negotiations, EU has started with the Stabilization and Association Agreement. Now Kosovo has to focus on the implementation of the reforms to meet its obligations under that Agreement. The political 
deal within the EU was met: the five countries which do not recognize Kosovo independence will not block its path to EU. But the international forces (EULEX, KFOR) are still present and the youngest country in the region is far away from functioning as an independent state.

Despite unfinished reforms, in comparison with the other Western Balkans countries, Albania is much more stabile one. As a NATO member (2009) Albania has achieved solid level of democratization. Due to it geostrategic position it is a gateway for trafficking people, drugs, money laundering and due to the lack of rule of law, still high level of corruption and insufficient border control lots of organized crime are taking place in Albania and in its neighborhood. The Albanian government has made some progress that was awarded with candidate status.

Bosnia and Herzegovina is at standstill. Together with Kosovo it takes lowest position on the EU's list; yet it is in worse position than Kosovo. The Stabilization and Association Agreement came into force but without consensus among ethnic elites of all three ethnic groups. Their ability to work together puts at risk the pre-accession EU assistance (Šolaja 2015). The country needs to implement the Sejdic-Finci judgment of the European Court of Human Rights, create a real single political and economic, but more importantly, the politicians have to create common state structures. Today the country is a case of dysfunctional political structure composed of fourteen governments and countless bureaucracies for a population of less than four million people (Anastasakis 2008, 371).

\section{Foreign actors in the region}

The US has been pretty involved in stabilizing the region after the dissolution of Yugoslavia. Nowadays the US diplomacy and military forces are not directly involved in the hot spots of the region but through its new approach of leading from behind they can help immensely. The US and EU presence is even more important in times when many other foreign actors are present; politically, financially, economically, via tourism, in the sphere of energy security, building infrastructures and so on. Struggling with economic recession, the Western Balkans countries, including Croatia, are searching for new sources for investment far from EU. For the period 2013-2014 the European Bank for Reconstruction and Development, the European Investment Bank and the World Bank together were funding cross-regional infrastructure projects worth 30 billion EUR. Yet, Turkey, Russia, China, Azerbaijan, some Arab states are major investors in the Western Balkans. They have 
invested a lot in energy sector trying to become major energy suppliers of some countries (Đorđevic 2014). With good infrastructure network and with the construction of the new pipeline via Western Balkans, they can easily reach the wider European market. Such diversification of investment partnerships across the Balkans reflects the global shift in the world economy. One can expect more foreign actors to come. If such trends continue, the West is not going to be the dominant player. But only the US and EU impose demands on each country to fulfill Western democratic standards. That is exactly what the region is still missing. The Balkan countries have to do their homework while EU, despite its own problems, have to keep its vision of free, democratic and united Europe. Stating that the door is open is not enough. Croatia has strongly to advocate for a such policy within the members of EU.

\section{Conclusion}

The EU-Western Balkans relations are governed by the Stabilization and Association Process. But the integration into the EU faces difficult times. Recent events, ranging from Ukraine to Greece, the Middle East and North Africa with a new surge in refugees trying to cross the Mediterranean Sea is pushing the Western Balkans into the background of European Neighborhood attention (Svoboda 2015). Instead of furthering enlargement policy there are new ideas of multi-speed, dual-track or two-speed Europe (Piris 2012). Others see it as downgrading of EU values because EU may then consist of countries that are in the centre and those who are in its periphery. The Western Balkans region will be the periphery of the periphery - countries that have an important stake in the current debates about the future contours of Europe, but no real voice (Bechev 2013).

The enlargement process is at crossroad (Vukadinvić and Čehulić Vukadinović 2011). It has happened before in international relations so it is nothing dramatically new. History shows that every time when the process of integration stopped (by any reason) a period of wars or disorder followed. The European integration has provided a period of relative stability, peace and prosperity. If EU postpone or stop this process, probably there will be a new wave of bloody wars like the ones twenty five years ago. The Western Balkans countries are now the only ones with a real prospect of membership. It is not sure if and when the EU is going to put the halted mission of enlargement again on its agenda. Judy Dempsey (2015) argues: "The EU is not quite sleeping, but it is watching the Western Balkans as it was not affected by events there. Worse the European Union does not have the right tools to 
address the challenges emanating from the region... The EU should consider a Copernican revolution for its enlargement policy".

Concerning contemporary international politics, the traditional Euro-Atlantic partnership has split. The US is focused on Asia and on other global challenges (China, Iran, Syria, ISIL), while Europeans are more concerned with their periphery (Ukraine, Greece, Turkey). The Western Balkans is in vacuum. The EU has strategic responsibility to fill that vacuum - otherwise it will be filled by other non-European competitors. Croatia should be reminder how crucial the role of the EU membership prospect was in the transformation of a society. Without continuous EU involvement, the Western Balkans will remain what it is now - fragmented, unstable, undeveloped, with political elites more reluctant to implement reforms and for a long time a trouble spot of Europe.

Croatia is engaged in the region bilaterally, regionally and within the European institutions. Integration of the Western Balkans into NATO and European Union is one of the main Croatia's interests. For that reason Croatia strongly supports the open door policy. As a border country Croatia needs stabile, predictable and peaceful neighborhood. Croatia has multi faceted engagement with the region. Yet there is still space for more cooperation.

\section{References}

1. Anastasakis Othon. 2008, "The EU's political conditionality in Western Balkans: towards a more pragmatic approach", Southeast European and Black Sea Studies, 8(4):365-377.

2. Annual Report of the Secretary General of the Regional Cooperation Council on Regional Cooperation in South East Europe 2014-2015, available at:

http://www.rcc.int/pages/75/annual-report-on-regional-cooperation-in-southeast-europe-2014-20145 approached July 19, 2015.

3. Bechev, Dimitar. 2012 "The periphery of the periphery: The Western Balkans and the Euro crisis", European Council of Foreign Relations, August 2012, available at http://ecfr.eu/page/-/ecfr60/western/ballkans/brief/aw.pdf, approached July 11, 2015.

4. Borzel, Tanja. 2011, When Europeanization Hits Limited Statehood. The Western Balkans as a Test Case for the Transformative Power of Europe, KFG Working Paper, No. 30. September 2011, Berlin, Frele Universitat, 
5. Božić, Nikola. 2011, "The South-East European regional security and the significance of intelligence and security services' cooperation in countering threats" in Regional security and Intelligence Cooperation in the Western Balkans and Global Asymmetric Threats, edited by Rienzo Stephen, Črnec Damir, Brožić Liliana. 59-67, Ljubljana, Demat.

6. Bugajski, Janusz. 2014. Conflict Zones. North Caucasus and Western Balkans Compared, Washington D. C., The Jamestoun Foundation.

7. Vukadinović Čehulić, Lidija.2013. "Croatia's entry into the European Union and perspectives of further EU enlargement to the Western Balkans", Megatrend Review, 10(3).3:31-48.

8. Dempsey.Juy. 2015. "Is the EU Sleeping on the Western Balkans", available at: http://canagieeurope.eu/strategiceurope/?fa=60069, approach May 13,2015.

9. Đorđević., Vladimir. 2014. "Bussiness Deals and Western Fears (Russian challenge in the Western Balkans)" availabe at http://www.cepolicy.org/westernbalkans, approached 25 April 2015

10. Joseph, P.. Edward. 2015."The Balkans, Interrupted. The Protests in Macedonia are Only the Beginning" available at http://www.foreignaffairs.com/articles/southeastern-europe/2015-05-10/balkansinterrupted, approached June 7, 2015.

11. Knaus, Gerald., Bender, Kristof.2012. "Why Croatia's EU accession will strengthen the EU", Rumeli Observer blog, 19 October 2012, available at http://www.esiweb.org/rumeliobserver/2012/10/19/whycroatias-eu-accessionwill-not-weaken-the-eu-in-english/, approached July 10,2015

12. Mitrevska, Marina. 2014"Implementation of the Ohrid Framework Agreement in the Army of the Republic of Macedonia", Sovremena Makedonska Odbrana, 14(26): 2336.

13. Murgasova Zuzana., Ilahi, Nadeem, Miniane Jacques. and an IMF Staff Team. 2015. The Western Balkans: 15 Years of Economic Transition, Regional Economic Issues Special Report, International Monetary Fund, Washington, D. C., International Monetary Fund.

14. Nić, Milan. 2013. "The EU's role in the Western Balkans after Croatian's accession", Policy brief, April 17,2013, Central European Policy Institute, available at: http://www.cepolicy.org/publications/eus-role-western-balkans-after-croatianaccession, approached July 15, 2015 
15. Piris, Jaun-Claude.2012. The Future of Europe. Towards a Two-Spead Europe?, Cambridge. Cambridge University Press.

16. Policy Advisory Group-Balkans in Europe. 2014. The Unfulfilled Promise: Completing the Balkan Enlargement Graz, Centre for Southeast European Studies, European Fund for the Balkans, May 2014.

17. Xhaferi, Talat 2015. Implementation of the Strategic commitments of the Republic of Macedonia to the Common Foreign and Security Policy of the European Union, Skopje, Institute for Political and International Studies

18. Sefearj, Klodjan 2015. "Expanded EU in the Western Balkans: Challenges to the Good Neighborhood Relations". In Euro Regions. Integrating Societies, Generation Growth, Caring Resources edited by Sela, Ylber 39-52.Skopje, Institute for Political and International Studies.

19. Sustainable Governance Indicators Survey 2015, Bertelsman Foundation, available at: http://www.sgi-network.org/2015/Croatia, approached July 9, 2015.

20. Svoboda Hannes .2015 "Western Balkans: new Hope coming from Berlin, Vienna and Paris", available at: http://www.ifimes.org/ba/9000\#sthash.ffhplng9.dpuf, approached July 2, 2015.

21. Šolaja, Miloš. 2015. "De Facto States and Regional Security Balancing." In Yearbook Šipan 2014., edited by Čehulić Vukadinović, Lidija.,77-88. Zagreb. The Atlantic Council of Croatia, Centre for international studies.

22. The Visegrad Group: Exploring New Agenda for the Western Balkans

23. CEPI-Central European Policy Institute, available at:

http://www.cepolicy.org/publications/visegrad-group-exploring-new-agendawestern-balkansPI, approached June 11, 2015

24. Veljanoska Katarina, Andonov Oliver and Shibakovski Goran. 2014 "The Democratization Process in the Western Balkans in the Last 20 Years: Interethnic Relations and Security Implications", Romanian Journal of European Affairs, 14(2):29-41.

25. Vukadinvić, Radovan., Čehulić Vukadinović, Lidija.. 2011. Politika europskih integracija, Zagreb, Ljevak,

26. Żornaczuk, Tomasz. 2013. The Prospect of the EU Enlargement to the Western Balkans, Bulletin, No.24, March 8, 2013, Warszaw, PISM. 